\title{
Atomaftale \\ frem for mere krig
}

\author{
Anders Jerichow
}

Atomaftalen bringer Iran og det internationale samfund tilbage på talefod. Ikke fordi Iran har ændret sin politik eller fordi Iran indstiller sit atomprogram og opgiver sine anlæg for berigelse af uran og slet ikke fordi Iran opgiver sin politiske kritik af USA og Israel eller sin rivalisering med Saudi-Arabien - men fordi verdens stærkeste magter har besluttet, at Iran er for vigtigt til at isolere. Uanset Israels højlydte og Saudi-Arabiens diskrete kritik.

Jo, de var glade i Geneve, da den historiske atomaftale mellem Iran og de fem faste medlemmer af FN's sikkerhedsråd og Tyskland blev indgået den 14. juli 2015 Men hvad var de glade for? Irans udsendte ministre var utvivlsomt glade for, at deres land nu slipper ud af internationale sanktioner, som gennem mange år har lammet den iranske økonomi. Og 'det internationale samfund' - repræsenteret af de seks stærkeste - var glad for en aftale, som i et vist mål lægger bånd på Irans atomprojekt.

Men uden for Geneve var og er andre magter alt andet end glade især de stater, aftalen forestiller at tilfredsstille. Lige som Mellemøsten har 'stedfortræderkrige' har den altid eksplosionsfarlige region nu fået en 'stedfortræderaftale'.

Atomaftalen er således alt andet end en fredsaftale - hvis en fredsaftale kan defineres som en aftale mellem hidtil stridende parter om at bilægge deres konflikt og satse på fred i stedet for.

Aftalen er knapt nok en egentlig nedrustningsaftale, for den ene part - Iran har konsekvent nægtet at have hverken det våben eller de militære ambitioner, som den anden part - de 5-plus-én - nu hævder at have lagt bånd på. Og selv hvis de 5-plus-én har ret i, at Iran var ved at skaffe sig teknologi og beriget uran til at kunne konstruere et atomvåben, afskærer aftalen ikke Iran fra at gøre præcis dét om 10-15 år, når aftalen rinder ud.

For det internationale samfund er 1015 år lang tid og flere amerikanske præsidenter væk. For enhver, der beskæftiger sig med atomvåben, og for alle magter i Mellemøsten er 10-15 år kun om et øjeblik.

Derfor er det ikke uvæsenligt, hvem 'stedfortræderaftalen' ikke omfatter og ikke forpligter. Hvis det grundlæggende problem var, at Irans atomprojekt gav dets rivaler eller potentielle fjender grund til uro, er det unægtelig centralt, at hver-

Anders Jerichow er journalist, mellemøstekspert og seniorkorrespondent på Politiken. Han optræder hyppigt som kommentator i radio og tv, og han har skrevet og bidraget til adskillige bøger. 
ken Saudi-Arabien, andre arabiske stater, Israel eller Tyrkiet var inviteret til at deltage i forhandlingerne i Schweiz. Irans præstestyre ville have nægtet at tale med Israel. Og hverken præstestyret i Teheran eller kongemagten i Saudi-Arabien ville have talt med hinanden. Tyrkiet ville utvivlsomt gerne have deltaget, men var ikke inviteret, for hvis Tyrkiet skulle deltage, ville det blive for påfaldende, at israelerne og saudierne ikke var inviteret.

Derfor påtog de $5+$ én sig officielt at tale med Iran på verdenssamfundets vegne reelt med henblik på for det første at undgå en akut væbnet konflikt mellem Israel og Saudi-Arabien på den ene side og Iran på den anden og for det andet at undgå et atomvåbenkapløb i Mellemøsten.

Det første lykkedes formentlig på kort sigt. Ingen storkrig lige her og nu (Mellemøsten har rigeligt med mindre krige). Det andet mislykkedes - ikke bare på længere sigt. Mellemøsten er reelt midt i et atomkapløb. Og Iran og dets omgivelser er midt $i$ en dramatisk konflikt, som atomaftalen ikke er i nærheden af at demontere.

\section{Forhandlinger under pres}

I aftalen bekræfter Iran, "at det under ingen omstændigheder nogensinde vil søge, udvikle eller købe nogen atomvåben”. Landet forpligter sig til at afstå fra en højberigelse af uran og til at acceptere international inspektion af anlæg, der er eller har været en del af Irans atomprogram. Det vil i 10 år udfase visse centrifuger og acceptere internationale overvågning af det atomanlæg i Natanz, Fordow m.fl. og acceptere ændringer af dets atomkraftanlæg i Arak. Samtidig vil de internationale og amerikanske sanktioner imod Iran gradvis blive afviklet.

Men hvad ved vi, og hvad ved vi ikke, om Irans atomprojekt?
Det vi ved er, at præstestyret i Teheran - ifølge FN's atomenergiagentur, IAEA $\mathrm{i}$ årevis har truffet teknologiske valg, som kan give militær og ikke kun civil mening. Vi ved, også fra IAEA, at de herskende præster har forsøgt at skjule Irans atomfaciliteter og at løbe om hjørner med IAEA. Det har skaffet sig avanceret teknologi til at berige uran i et omfang og et tempo, som kom bag på IAEA, og som Iran først har vedstået i takt med, at IAEA's efterretninger gjorde andre forklaringer håbløse.

Vi ved også, at Iran har satset økonomisk og teknologisk på at udvikle ballistiske raketter, der potentielt kan medbringe atomvåben, og som potentielt vil kunne nå alle storbyer i Saudi-Arabien og Israel, for den sags skyld også i samtlige andre arabiske golfstater, Egypten og Tyrkiet - og for den sags skyld naboer på den anden side af Iran, altså Pakistan, Afghanistan og det sydlige Rusland.

Det, vi ikke kan vide med total sikkerhed, er, hvor langt præstestyret i Teheran i virkeligheden er nået. Det sidste halvår blev forhandlingerne i Teheran ført under amerikanske opfattelser af, at Iran kun var nogle måneder, ikke flere år, fra at have eller kunne have tilstrækkeligt meget beriget uran til at konstruere en enkelt simpel atombombe.

I det perspektiv blev forhandlingerne både ført under et teknologisk og et militært tidspres. Teknologisk, fordi Iran kom nærmere og nærmere til at have beriget uran og raketter til et atomvåben. Og militært, fordi Israel og Saudi-Arabien gerne lod forstå, at de var parat til at standse Irans atomprojekt, hvis ingen andre, læs: USA, ville gøre det.

\section{God grund til atomvåben}

Hvad ved vi så om atombalancen i Mellemøsten, hvor det tydeligvis er så vigtigt 
for så mange stater at hindre Iran $i$ at blive en atommagt?

Det vi ved er, at Iran er omgivet af atomvåben, ikke hos venner, men hos stater, der ikke er Irans venner eller allierede. USA har permanent atomvåbenbestykkede flådefartøjer i Den Persiske Golf og Den Arabiske Havbugt. Rusland har atomvåben nord for den iranske grænse. På den østlige grænse har Pakistan for længst udviklet atomvåben - lige som Indien lidt længere væk. Og selv om Israel ikke indrømmer det officielt, er det almindelig anerkendt, at Israel i årtier har været en atommagt.

I det lys ville det ikke være underligt, snarere indlysende, at Iran - en historisk stormagt i Mellemøsten - også udvikler atomvåben.

Og fem-plus-én-forhandlingerne i Geneve bygger på den klare antagelse, at uden aftalen ville Iran i løbet af kort tid være i stand til selv at bestemme, om det skal have den ultimative bombe. Hertil siger kritikere gerne, at atomvåben ikke duer i Mellemøstens tætte byområder. Man kan ikke ramme Israel med et atomvåben uanset om man går efter Tel Aviv, Jerusalem eller Dimona, hvor Israel skal have sin egen militære atomfacilitet - uden også at ramme hellige muslimske steder og bringe død og ødelæggelse over lige så mange muslimske palæstinensere som jødiske israelere. Og tilsvarende vil det være svært at kaste sig ud i et atomangreb på Saudi-Arabiens beslutningscentre uden at bringe Islams allerhelligste i risiko.

Det lyder meget snusfornuftigt. Men atomvåben er som bekendt ikke beregnet til at bruge - men til at afholde andre fra at tage tilsvarende våben i brug, til at sikre sig en grundlæggende usårlighed eller i hvert fald en evne til gensidig destruktion. Med andre ord: Respekt.

Vil atomvåben i det lys give mening for
Iran? Ja. Præstestyret behøver populært sagt ikke have sat den sidste skrue i sådan et våben. Men alene en anerkendt evne til at kunne udvikle et atomvåben, hvis man ønsker det eller får brug for, vil umiddelbart forlene Iran med en stormagtsstatus, som kræver, at andre stater i området behandler det med respekt.

Men magtbalancen i Mellemøsten er ikke to-dimensional, men mange-dimensional. Ligesom USA \& Sovjet/Rusland og Pakistan \& Indien og Nordkorea \& (USA i) Sydkorea var nødt til - eller rettere har følt sig nødt til - at afbalancere hinanden, tænker Mellemøstens regeringer i balance. Det handler ikke om ret eller uret, men om magt. Hvis Israel har et atomvåben, vil det ikke overraske nogen, at Iran også i hvert fald vil være i stand til selv at bestemme, om det skal have en A-bombe. Og hvis Iran vil have teknologien, vil Saudi-Arabien også have teknologien. Og hvis de andre er i gang med atomkapløb, vil flere magter have militær tilbøjelighed eller politisk tilskyndelse til at engagere sig - fx De Forenede Arabiske Emirater, der har råd, og Egypten, den arabiske verdens mest folkerige nation, der har en iboende opfattelse af forpligtelsen til militært lederskab.

Det, vi ved om atombalancen efter Geneve-aftalen, er, at Iran allerede i kraft af det langstrakte forhandlingsforløb må være tæt på det punkt, hvor præststyret selv kan bestemme, om det vil have en bombe. Centrifugerne og teknikerne i Iran har ikke været i venteposition, mens forhandlingerne er foregået. Men efter aftalen ved vi, at Iran har accepteret i en begrænset årrække at berige mindre uran og at give IAEA en vis adgang til overvågning. Til gengæld ved vi også, at Iran ikke har forpligtet sig til helt at opgive sine teknologiske landvindinger, heller ikke sin evne til 
at berige uran i fremtiden. Den islamiske republik kan, når aftalen løber ud, i princippet og i praksis genoptage sin teknologiske udvikling med militære perspektiver.

For de fem-plus-én giver det mulighed for nye forhandlinger. For Iran er det tvivlsomt, om verdens politiske og økonomiske stormagter efter 10-15 år med forventet massive økonomiske investeringer i Iran og dets vældige marked med 80 millioner udviklingshungrende indbyggere, vil vende tilbage til sanktioner, der i givet fald vil trække tæppet væk under investeringerne.

\section{Saudi-Arabiens svar}

Hvad ved vi så ikke om atombalancen? Vi ved ikke, hvad Iran mere måtte have skjult for sine forhandlingspartnere. Vi ved heller ikke, hvordan og hvor hurtigt Saudi-Arabien vil skaffe sig den samme teknologi, som Iran har nået at udvikle. Israelske efterretningskilder lod os allerede for hen ved fire år siden vide, at det saudiske kongehus havde givet Israels luftvåben overflyvningstilladelse til et (fælles) angreb på iranske atomanlæg. Amerikanske medier, senest Wall Street Journal, har også afsløret, at Israel i 2012 syntes så langt i sine forberedelser på et angreb på atomanlægget Fordow i Iran - USA opdagede, at israelske fly gennemførte prøveflyvninger over Iran - at USA sendte et ekstra hangarskib til regionen og satte sine kampfly på skibet i ekstra beredskab.

Israel søgte dengang adgang til at købe ekstremt kraftige bomber, som USA angiveligt har udviklet specielt for at kunne gennembryde de forsvarsværn, som formodes at omgive anlæg som dem i Fordow. Men Israel fik dengang hverken de våben, den ammunition eller den opbakning, det søgte i USA til at angribe Iran. I de samme måneder forhandlede amerikanske og iranske udsendinge hemmeligt i Oman. Saudi-Arabien og åbenbart Israel var ikke parat til at gå i krig med Iran uden grønt lys fra USA. Det efterlader i saudiske øjne Israel med et atomvåben og Iran med evnen til at bygge et A-våben. Hvad så, Saudi-Arabien?

Det har både et kortsigtet og et langsigtet svar. På langt sigt har Saudi-Arabien med verdens største kendte olieressourcer besluttet at etablere atomanlæg ud fra det samme rationale som Iran - at det har ret til civil atomteknologi uagtet al tvivl om noget økonomisk behov. Men saudierne lægger ikke skjul på, at det vil have samme teknologi som Iran, som det anklager for militære ambitioner. Og på kort sigt har det saudiske kongehus ifølge solide militære efterretninger besluttet at springe den lange udviklingsproces over ved at minde Pakistan om, at det skylder Saudi-Arabien en tjeneste for mange års økonomisk og militær hjælp, også i Afghanistan. I saudiske øjne er det pakistanske atomvåben ikke mindst udviklet med bistand fra netop Saudi-Arabien - og på den baggrund skal Saudi-Arabien have skaffet sig adgang til et atomvåben på lagret i Pakistan. Saudi-Arabien råder allerede over kinesiske CSS-2-ballistiske raketter, som vil kunne medbringe atomvåben.

I givet fald: Så er Saudi-Arabien nu eller om et øjeblik også en tærskelmagt. Balancen er genoprettet. Så har Israel og Iran ikke noget, Saudi-Arabien ikke også har selv om saudierne fortsat skal bruge flere år på selv at bygge et atomvåben.

\section{Anerkendelse af 'tærskelmagt'}

Hvis alt dette er rigtigt - at Iran allerede har evnen til at bygge et atomvåben, når det passer præstestyret, og Saudi-Arabien har skaffet sig eller kan skaffe sig adgang til et atomvåben, når det passer kongehuset hvad har Geneve-aftalen så nyttet? 
Det vi ved er, at Iran er omgivet af atomvåben, ikke hos venner, men hos stater, der ikke er Irans venner eller allierede. USA har permanent atomvåbenbestykkede flådefartøjer i Den Persiske Golf og Den Arabiske Havbugt. Rusland har atomvåben nord for den iranske grænse. På den østlige grænse har Pakistan for længst udviklet atomvåben - lige som Indien lidt længere væk. Og selv om Israel ikke indrømmer det officielt, er det almindelig anerkendt, at Israel i årtier har været en atommagt. I det lys ville det ikke være underligt, snareге indlysende, at Iran - en historisk stormagt i Mellemøsten - også udvikler atomvåben.

Militært kan aftalen have udskudt det tidspunkt, hvor Iran kan skrue de sidste møtrikker i et eget atomvåben.

Politisk har aftalen reelt anerkendt Iran som en tærskelmagt, som det internationale samfund ikke har råd til at isolere, men har et stærkt behov for at være på talefod med. Det staves r-e-s-p-e-k-t på iransk. Og det er i sig selv helt afgørende for al iransk positionering - at Teheran nægter at blive ringeagtet i forhold de arabiske kongemagter på den anden side af Den Persiske Golf og nægter at blive behandlet som en kasteløs af vestmagterne.

Selv om Geneve-aftalen påfører Iran en vis international overvågning, der opfattes som ydmygende af de mest konservative grene af præsteskabet og deres allierede i Revolutionsgarden, så giver fjernelsen af de økonomiske sanktioner andre iranere en oplevelse af genvunden respekt og en geninddragelse i internationalt samarbejde, hvor de fleste iranere vil opfatte deres land som en stormagt.

Her er Iran og vestmagterne - og Rusland og Kina - enige: Det giver ingen mening at isolere Iran.

Vestlige stater er efter Geneve-aftalen i fuld gang med at genoprette eller genopvarme deres diplomatiske forbindelser. De første vestlige ministre fra Tyskland og Frankrig har allerede aflagt besøg i Teheran. De første handelsaftaler er underskrevet. Fra at være et land, man ikke taler med, er Iran blevet et land, man handler med.
Men Iran har ikke indstillet den militære udvikling, som bekymrer eller provokerer USA - og dets allierede Israel og Saudi-Arabien. Den 10. oktober 2015, to måneder efter indgåelsen af atomaftalen, gennemførte præstestyret under stor politisk bevågenhed en testaffyring af en avanceret målsøgende mellemdistanceraket, Emad eller 'Søjle, som kan medføre atomvåben. Ifølge den amerikanske $\mathrm{FN}$-ambassadør Samantha Power var det i klar modstrid med sikkerhedsrådsresolution 1929, som siden 2010 har forbudt Iran at foretage prøveaffyringer af den type våben.

USA, Storbritannien, Frankrig og Tyskland indbragte sagen for Sikkerhedsrådet. Men hverken Rusland eller Kina - og reelt heller ikke USA og de europæiske regeringer - var parate til at pålægge Iran nye sanktioner kort før, at den nye atomaftale kunne træde i kraft. Det vil ske, når IAEA mener, at Iran lever op til vilkårene. Atomaftalen forbyder ikke Iran at arbejde med udvikling af mellem- og langdistanceraketter, men i en otte års periode vil det kræve sikkerhedsrådets tilladelse for andre stater at sælge og overføre missilteknologi og tunge våben til Iran.

Præstestyret gentager ved enhver lejlighed, at dets raketter slet ikke er designet til at medbringe atomvåben. Iranerne har siden 1992 produceret sine egne missiler, som ifølge præstestyret selv har en rækkevidde på 2000 kilometer - eller rigeligt til at nå saudiske og israelske mål. Rusland lovede allerede i foråret - inden indgåel- 
sen af atomaftalen i Geneve - at eksportere luftforsvarssystemet S-300 til iranerne. I begyndelsen af oktober, inden aftalen trådte i kraft, var Rusland ifølge Iran begyndt at levere systemet.

\section{Flere krige - fortsat rivalisering}

Ligesom stedfortræderaftalen ikke tog de lande, den skulle betrygge, i ed - så har den heller ikke så meget som antydet en udvej på de stedfortræderkrige, der stadig hærger Mellemøsten med Iran og SaudiArabien på hver sin side.

I USA talte politikere og medier under forhandlingerne om 'den store aftale', der ville koble atomspørgsmålet sammen med en løsning på krigene i Syrien og Irak. Rationalet skulle være, at hvis Iran slap fri af de snærende internationale sanktioner, så ville præsteskabet samtidig være tilbøjeligt til at hjælpe med en afvikling af Assad-diktaturet i Syrien. Noget for noget.

Således ikke. Den øverste åndelige vejleder i den iranske revolution, Ayatollah Khamenei, har slået fast, at Iran afviser at forhandle eller handle med USA om sine andre interesser i Mellemøsten. Det får amerikanske og iranske eksilkritikere af atomaftalen til at fremføre, at atomaftalen tværtimod vil give Iran råd til bedre at finansiere præstestyrets involvering i Syrien, Irak, Libanon og Yemen.

Det er uomtvisteligt, at Iran har investeret militært og økonomisk i at sikre det syriske diktatur under Bashar al-Assad. Iranske revolutionsgardister kæmper sammen med syrisk militær, og iranske militære rådgivere har ifølge vestlige efterretninger fra Syrien ligefrem fået en dominerende rolle i Syriens militære kommando.

Det er også uomtvisteligt, at Irans præstestyre fortsat er den vigtigste sponsor og våbenleverandør til den libanesiske Hizbollah-bevægelse, som det seneste år i Sy- rien har leveret de kampduelige soldater, som har beskyttet Assad mod et militært nederlag. Assads militær er stærkt presset af titusinder af deserteringer og lige så mange unge mænds flugt fra landet. Syrien, der tidligere rådede over den arabiske verdens stærkeste militær, er i dag derfor konkret afhængigt af tropper, som Iran kan levere i form af såvel egne revolutionsgardister som militsfolk fra den libanesiske og den irakiske Hizbollah-bevægelse.

Mindre uomtvisteligt er det ikke, at Irans revolutionsgarde i Irak har udrustet, trænet og anført shiitiske militser, der kæmper bedre mod IS-bevægelsen end landets eget nye militær, og som derfor har fåt en afgørende indflydelse i Irak.

Samtidig har det - langsomt, men dog - vist sig, at hvis den yemenitiske Houthi-bevægelse, som i foråret 2015 erobrede magten i Yemens hovedstad, Sana'a, har nogen allieret udefra, så er det Iran.

Intet tyder på, at Houthi-bevægelsen, som i årevis har domineret det nordligste Yemen med egne militære styrker og egen skatteinddragelse, hverken var styret eller afhængig af Iran, da Saudi-Arabien sammen med andre arabiske magter indledte en bombekampagne mod bevægelsen i foråret 2015. Men amerikanske flådestyrkers standsning af skibe med våben på vej til Yemen og Houthi-bevægelsen i løbet af sommeren har givet Saudi-Arabien noget at have sin frygt for iransk indblanding $\mathrm{i}$.

I saudiske øjne har det persiske Iran ikke alene blandet sig i Libanon, Syrien, Irak og Yemen, men reelt skaffet sig en afgørende indflydelse i disse fire arabiske stater tæet på Saudi-Arabien.

Hertil vil Irans præstestyre sige, at landet ganske lovligt er inviteret af regeringerne i Syrien og Irak til at stå dem bi. Præstestyret vil også sige, at Hizbollah er en lovlig bevægelse i Libanon, selvom den af vestli- 
ge regeringer opfattes som terroristisk, og at den iranske hjælp til Hizbollah ikke bryder den form for orden, der hersker i Libanon. Og dels afviser Iran at have startet krigen i Yemen, dels minder Iran om, at det faktisk er Saudi-Arabien, der med en massiv bombekampagne er ved at blande sig i Yemens politiske udvikling ved at bombe væsentlige bysamfund sønder og sammen.

I hvert af disse fire arabiske lande - Syrien, Irak, Yemen og foreløbig mere fredeligt i Libanon - er lokale bevægelser i konflikt med andre bevægelser. Men i alle de fire lande er Iran og Saudi-Arabien heftigt involveret. Politisk. Økonomisk. I en eller anden forstand med våben. Reelt er det en stedfortræderkrig eller en rivalisering om regionalt herredømme mellem den Persiske Golfs to stormagter, Iran og Saudi-Arabien - som begge står bag store pengestrømme, våbenleverancer og i nogen udstrækning aktiv krigsførelse.

\section{Bedre end alternativet}

Atomaftalen bringer Iran og det internationale samfund tilbage på talefod. Ikke fordi Iran har ændret sin politik. Ikke fordi Iran indstiller sit atomprogram. Ikke fordi Iran opgiver sine anlæg for berigelse af uran. Tværtimod har Irans øverste leder, Ayatollah Khamemei, gjort sin godkendelse af aftalen betinget af, at Iran kan fortsætte sin forskning og udvikling inden for berigelse af uran, så det ikke efter aftalen kommer bagefter. Og slet ikke fordi Iran opgiver sin politiske kritik af USA og Israel eller sin rivalisering med Saudi-Arabien. Men fordi verdens stærkeste magter har besluttet, at Iran er for vigtigt til at isolere. Uanset Israels højlydte og Saudi-Arabiens diskrete kritik. Aftalen blev ikke godkendt af den amerikanske kongres, kun ført igennem, fordi kongressen ikke kunne mønstre et tilstrækkeligt flertal til at nedlægge veto mod præsidents vilje.

Men alternativet? Rusland og Kina ville ikke lægge et hårdere pres på Iran. USA ville ikke gøre det alene. Europæerne, dvs. Storbritannien, Frankrig og Tyskland, troede og tror mere på et voksende samarbejde med Iran - selv med dets veludviklede atomare højteknologi - end på voksende isolering af præstestyret, uanset at det byder dem imod. Og i USA havde præsident Obama al grund til at frygte et voksende konservativt, et israelsk og et saudisk krav om militære indgreb mod iranske anlæg, som de opfattede som en trussel.

Et angreb på atomanlæg i Iran kunne i bedste fald sætte iranske atomprojekter flere år tilbage. Men i værste fald kunne angrebet udløse en uoverskuelig krig med risiko for at bringe Mellemøsten helt ud af balance, altså endnu mere ud af balance end i dag, hvor hver tredje arabiske samfund allerede er i krig eller krise. Mellemøsten har brug for det modsatte, altså balance.

Aftalen giver med lidt held og effektiv international overvågning alle parter 1015 år til at tænke sig bedre om. Det er ikke kun USA, som vil have en anden leder til den tid. Det vil Israel, Saudi-Arabien, formentlig Iran, måske endda Rusland, også. Det lover ikke, at Mellemøsten ser anderledes ud. Men det giver i hvert fald en mulighed for at lade konfrontation afløse af forsoning og - hvem ved? - af samarbejde.

Atomaftalen anerkender Iran som en regional stormagt snarere end demonterer Iran som tærskelmagt. Det er eller bliver Iran under alle omstændigheder. 